\title{
Responding to the character education on the tradition of mopolihi lo limu (lemon bathing) at Gorontalo
}

\author{
Razak H. Umar \\ Faculty of Education and Teacher Training IAIN Sultan Amai Gorontalo \\ razakumar67@gmail.com
}

DOI: $10.18326 /$ attarbiyah.v4i2.207-228

\begin{abstract}
Character building has become strategic way for government to prepare Indonesian golden generation on 2045. President Regulation Number 87 Year 2017 about Reinforcement of Character Education (PPK) suggests 18 students' character value through the harmony of psyche building, sense building, thought building, and physical building. Those could be implemented through the development of local wisdom and the improvement of special character and identity of a region. Gorontalo is one of nineteen regions in Indonesia which regulates local laws has various local laws, one of them is Mopolihu Lo Limu (Lemon Bathing) for female children under 1 to 3 years old. Mopolihu Lo Limu tradition has numbers of values which are relevant to the Reinforcement of Character Education (PPK) such as: (1) Religiosity, (2) Honesty, (3) Tolerance, (4) Discipline, (5) Hard work, (6) Independent, (7) Love the Mother Land, (8) Friendly, (9) Love Peace, (10) Social Awareness, (11) Environment Awareness and (12) Responsible. This research used descriptive qualitative method which was relevant to the object. It took place at Gorontalo as the research setting. The object of the research was the Mopolihu Lo Limu (Lemon Bathing) for female children.
\end{abstract}

Keywords: Local Wisdom, Mopolihu Lo Limu, Character Education 
Attarbiyah: Journal of Islamic Culture and Education

https://www.attarbiyah.iainsalatiga.ac.id/index.php/attarbiyah/

\section{INTRODUCTION}

Gorontalo is one of nineteen indigenous territories which is officially admitted its customary jurisdiction in this country (Vollenhoven, 2011). This customary law is the original law for Indonesian origins. The source of the law was from unwritten regulation which is developed and preserved by the society consciously. Its territory is located at the lengthways from east to west of the north area of Sulawesi island. The north are is bordered with the Sulawesi sea, the east area is bordered with the province of North Sulawesi, the west is bordered with the province of Central Sulawesi, and the south is bordered with Tomini Bay. The majority of Gorontalo societies are Muslim. The cultures and traditions are influenced by Islamic teaching and values. Thus, Gorontalo societies keep up their custom motto that, 'Adati hula hula'a SareatiSareati hula hula'a to Kitabullah wich means traditions are based on Syara, Syara are based on the holy book of Allah (Pemkab II Gorontalo, 1942-1985).

Practically, Gorontalo tradition is facing dynamic problem on social life. The rapid development of social community at Gorontalo demands transformation which corresponds to the current need and development of era. This new province has various traditional ceremony which other condition of customary territories in Indonesia face that the traditional ceremony has shifted its value and the implementation, however, such traditional ceremony which is based on Syara' values and the holy book of Allah or Kitabullah should be preserved, one of them is Mopolihu Lo Limu (Lemon Bathing). The attempt to preserve such tradition is because there are many moral values which could be used to shape the generation characters. All series of traditional ceremony tools, the process and the words spelled by the tradition holder are meaningful for shaping human character. Based on this 
consideration this article is written. The writer would like to recognize what aspects are found in the tradition of Mopolihu Lo Limu (Lemon Bathing), the education character values and its relevance to the proof from Al-Qur'an and Hadis as the implementation of the tradition philosophy which based on syara, and syara is based on the holy book of Allah Kitabullah.

Tradition is a regulation among society which its truth are admitted by certain society (Susylawati, 2009). Tradition which is owned by certain society is different from other society. Territory law is the whole regulations which regulate the Indonesian behavior, while there are sequences for those who violate it, and it is unwritten (Syahbandir, 2010). Law is social rule which is not separated with the value which exists in the society.

Character education should be implanted toward children. The reinforcement of character education shapes children to own good character and politeness so that they are admitted in the society (Judiani, 2010). Character education is able to improve nation children character which is full of civilization. This correlates with the purpose of why our prophet was sent to the earth that is to accomplish human morals which means that humans should own good character. Generally, almost schools emphasize on students cognitive intelligence, perfect score, and students' talents but they forget their character education. Thus, the reinforcement of character education especially on the tradition of Mopolihu Lo Limu (Lemon Bathing) should be emphasized to create children with good character in all sites. According to the description above, it needs clear explanation of the existence of Mopolihu Lo Limu ( Lemon Bathing) tradition in Gorontalo. 
Attarbiyah: Journal of Islamic Culture and Education

https://www.attarbiyah.iainsalatiga.ac.id/index.php/attarbiyah/

\section{METHODS}

This research used descriptive qualitative which was relevant to the object of research. This research took place at Gorontalo. The object of this research was the tradition of Mopolihu Lo Limu (Lemon Bathing) for 1-3 years old female children. The primary source of this research was the territory law and tradition at Gorontalo as the additional source. The techniques which were used to collect the data were observation and documentation which were checked using data triangulation. The data were analyzed through the elaboration and description of research data through the observation and documentation which were collected during the research.

\section{DISCUSSION}

\section{Tradition of Mopolihu Lo Limu (Lemon Bathing) at Gorontalo}

Pohutu Aadati Lihu Lo Limu is one of tradition from Gorontalo which should be conducted to the female children as a way for islamization and selftreatment for women in Gorontalo starting from their early children up to their adulthood. This traditional ceremony is one part of baby born traditions for female children around one to three years old. The ceremony of Pohutu Aadati Lihu Lo Limu consists of three phases; each phase has series of traditions which supplement each phase and validate the ceremony. The first phase is mongubingo atau mongulu'o (female circumcision); the second phase is Mopolihu Lo Limu (bathing using fragrance water or lemon water); and the third phase is mopohuta'a to pingge (stepping on seven plates).

Mopolihu Lo Limu words was derived from Gorontalo language which means bathing using potion of lime water or lemon water. According to the 
terminology of Gorontalo tradition, Mopolihu Lo Limu means that a process of bathing female babies or children using potion of lime water. The potion consists of seven elements, as follow: (a) Taluhu Yilonuwa (potion of limututu lime water), (b) The flesh of Limutu (lime) which is thinly sliced, (c) Seven Limututu lime which are cut into half without squeezed, (d) The slices of seven kinds of croton leafs (polohungo), (e) Potion of Umoonu (with fragrant) which is mashed smoothly called Yilonta, (f) Onumo leaf, it is such a mayana leaf but it has green color and soft and (g) Jasmine called Bungamoputi. It has become tradition AT Gorontalo That every female child who will reach two years old will have a Mopolihu Lo Limu traditional ceremony or they usually call it as Molubingo (pinch). The terminology of mongubingo in Islam is circumcision (Botutihe dan Farha Daulima, 2013).

The tradition of Molubingo (Pinch) and Mopolihu Lo Limu (Lemon Bathing) is a tradition which is held by community hereditary from generation to generation. The ceremony of female is part of Mopolihu Lo Limu ceremony which precedes circumcision ceremony. On the other hand, before holding circumcision ceremony, we should conduct Mopolihu Lo Limu (Lemon Bathing).

The Mopolihu Lo Limu (Lemon Bathing) ceremony is conducted by Hulango (village midwife), Priest (Hatibi) and an eldered mother. Not all Hulango could be a Hulango except they have reached number of requirements. There are four requirements of becoming a Hulango, they are Muslim, they know how to conduct series of Mopolihu Lo Limu and Mongubingo (Pinch), they memorize the spell which was brought down by the ancestors and she is admitted by the society as the Hulango (Yasin, dkk, 2013). 
The first thing we do before conducting circumcision is cleansing the vagina using ablution water. This process is held in a room, the child is seated on her parent's lap and is covered with white cloth then the circumcision is proceeded or Mongubingo (Pinch) by Hulango (village midwife). The eldered mom takes part as the supervisor of this ceremony. The preacher serves as Shalawat reciter (mongadi salawati). Ngadi salawati is held in the morning before Mopolihu Lolimu and Mongubingo are held. It is continued with Momonto to the baby/ child and the parent or her aunt when child's mother is lapping her. The next splash is that when the mother and child are brought into Mopolihu Lo Limu. The mother and child are seated on Dudangata (Coconut shave), called splash. The first splash is splashed by the mother or represented to the grandmother then it is continued by the father. Both of them take the water from its place (Loyangi potion). The next splash is from tradition holder or preacher (hatibi), which is taken from yellow bamboo perian (the first perian without sujai). The second splash using perian up to seventh splash is held by Hulango. When the grandparents from the child's mother or father are still alive, they are also asked to splash the perian (Daulima dalam Yasin dkk, 2013).

After the bathing process, the child is made up using traditional custom: a long dress namely $\mathrm{O}$ Tambi'O (decorated with golden flowers), and wear baya lo bo'ute (headband), then they do circumsition to the child. The Hulango covers herself using Alumbu Moputio (white cloth) during the circumsition process. After the process is done, the child is swept with Yinulo Moonu (perfume) as the alert that the process is done. Then, the preacher recite a prayer as the form shukr which is in front of him is polutube (ember 
place). After the prayer done, the ceremony is continued with eating together and closing.

\section{Character Education}

Education character is basic fundament to improve the nation generation. Good character generation will realize strong and dignified nation. Character is description of personal behavior which shows the value of true or false, implicit and explicit good or bad (Alwisol, 2006). Thus, preparing qualified generation is conducted through strengthening character education through formal and informal education. Character education actually does not only teach the value of true or false but also how to implant good behavior to children so their future will follow the value of good behavior. This concept makes character education is also known as value education, education which consists of personal value.

The first theory which discussed character education is pedagogic theory by Foerster in Koesoema (2007). This theory emphasizes on the spiritual ethical aspects to shape child's character. Character education are characterized as follows; 1) emphasizes on the value as the normative guidance of children behavior; 2) emphasize on children self-endurance so that they have natural constancy to keep their self-principal, 3) own independency, 4) own durability. This theory emphasizes on the content of character education, ethical spiritual values which are realized on the moral education for children. The implementation of this concept on formal education in Indonesia is by obligating students to take religion education and civic education because both subjects contain children moral development (Fajarini, 2014).

In the context movement development, the reinforcement of Character Education (PPK) is prioritized on five values: religious, nationalism, 
integrity, independent, and cooperativeness. Those values could not stand alone; it is connected to each other, develops dynamically, and forms a whole personal character. Religious character value reflects personal faith toward the One Almighty God which is shown in the person's attitude by doing all the commands of his religion and belief, respect to the religion diversity, uphold the tolerance of the implementation of worship and live in harmony with other religion worshipers. The implementation of religious value is shown on love peace, tolerance, tolerate the diversity of religion and belief, strong determination, confidence, cooperation among other religion and belief worshiper, anti-bullying and violence, love environment and protect the minority.

Nationalist character value is the way to think, behave, and act which show the loyalty, awareness, and high respect toward language, physical environment, social, culture, economy, nation politics, and put the national affair highest from the personal and community affair. Nationalist is shown through appreciating culture of their nation, preserving the nation cultural riches, being willing to sacrifice, being superior, being achievers, loving the mother land, protecting the environment, being obedient, being discipline, and respecting the diversity of culture, tribe, and religion.

Integrity is a value which underlies attitudes which are underlid on the personal attempt to be a person who is trusted on his words, actions, works, and owns commitment and loyalty on moral and humanity values. Integrity includes responsibility as citizen and being active in the social activities through the consistence of trusted words and attitudes. Integrated person also respects to the personal dignity (especially person with disability) and shows his exemplary. 
Independent character is described with person's attitude and behavior which does not depend on other people and force their whole energy, thought, and time to realize his dream and ambition. An independent student has good work ethic, toughness, and powerless, professional, creative, brave, and long live learners.

Cooperative character respects cooperative spirit and work together to sove a problem, interact and communicate each other, and help everyone who needs. It is expected that students respect each other, work together, be inclusive, and be able to commit with the final decision, be deliberation, help each other, have empathy and solidarity, anti-discriminating, anti-violence, and be voluntary.

\section{Islamic Education Values in the Tradition of Mopolihu Lo Limu (Lemon Bathing)}

Government policy which put the character development as the core of education demands all stakeholders including society to take part in building the students' character. President regulation Number 87 Year 2017 regarding of the reinforcement of education character mandates that to realize cultural nation, it needs the reinforcement of character education by strengthening 18 character values including religious, honest, tolerant, discipline, hard work, creative, independent, curiosity, spirit of nationality, love the mother land, respect the achievement, communicative, love peace, love reading, care the environment, care the social, and responsible.

The sources which can be used to improve the students character can be sourced from the implementation of religious values and other values such as from local wisdom. In this context, the local wisdom is the tradition of Mopolihu Lo Limu (Lemon Bathing) as one of traditional ceremony from 
Gorontalo which can be reference values to improve students' character. There are many values which can be retrieved from Mopolihu Lo Limu (Lemon Bathing) tradition, from its ceremony, ornament and text spelled during the ceremony. The components of this ceremony are meaningful for strengtening character education. It is identified that there are thirteen values which can be developed through Mopolihu Lo Limu (Lemon Bathing) tradition ; religious, honest, tolerant, discipline, hard work, independent, democratic, love mother land, communicative, love peace, care of environment, and responsible. The elaboration of those values are described below:

1. Embed the Cleanliness (Taharah) and Health

Cleanliness value is seen from the first and second step of this tradition on Molukobu (pinch/circumcision) and Mopolihu Lo Limu (lemon bathing) steps. Molukobu (pinch/circumcision) is a step where there is process of realizing something from the child's vagina. It is conducted since circumcision is not only Allah's command but also as the requirement on the perfection of someone's praying, reciting Quran, hajj and other worship activity which require cleanliness from hadaa and unclean body.

"And they ask you about menstruation: say, "It is harmful, so stay away from women during menstruation. And do not approach them until they have become pure. Once they have become pure, approach them in the manner God has directed you." God loves the repentant, and He loves those who keep clean.”" (Q.S Al-Baqarah verse 222).

Thus, it is required for female children to have circumcision to keep their' cleanliness, teach them to live cleanly and health, and be clean while worshipping. After conducting Molukobu (pinch/circumcision) or 
realizing unclean thing, it is continued with Mopilihu Lo Limu (lemon bathing) cleaning children using lemon water potion. They are also splashed with taluhu moonu potion sourced from any fragrances.

2. Embed Sharia Values

In Islamic teaching, Molukobu (pinch/ circumcision) is one of media to purify children spirit and becomes proof of their obedience to the religion. Molukobu (pinch/circumcision) is one of Islamic sharia which becomes Sunnah of our prophet Muhammad PBUH even it is required on Abraham prophet era. There are many hadiths which require them to conduct circumcision.

In fact, Circumcision (Molukobu) was firstly conducted in Abraham PBUH era. He was the first person who are being circumcision when he was eighty years old; it was told by Muhammad prophet PBUH which was narrated by Abu Hurairah: "Prophet Abraham PBUH, God the Merciful's dearest had circumsision as sharia after he was eighty years old, and he conduted it at or using qadum." (H.R. Bukhari) (Zohra Yasin dkk, 2013).

The implementation of circumcision or it is known as Molukobu (pinch/circumcision) at Gorontalo is obligation based on Imãm Syafi'i madhhab which is supported by the majority of preacher which see that circumcision is required for male and female Muslim children. This madhhab is based on Allah argumentation on His commandment regarding of Allah's command to Muslim to emulate Abraham prophet and Prophet Muhammad Hadis about someone who just convert to Islam (Utomo, Setiawan Budi, 2003). This Madhhab is based on the following hadith, "And who is better at religion than one who sincerely surrenders 
himself to Allah, is also doing good, and he follows the righteous religion of Abraham? and Allah took Abraham to be His favorite ". (Q.S Q AnNisa, ayat 125).

This argumentation explains that someone who abandons himself to Allah, does good things, and follows Abraham religion teaching (in this case the teaching is circumcision) are suggestions for Muslims. The benefit of circumcision from sharia site is that they follow Allah and Prophet Muhamamd PBUH sharia.

3. Embed Akhlãq (Moral) Value

One of elements which is conducted in Mopolihu lo Limu (Lemon Bathing) is Taluhu Moonu (Lime Water Potion). There are seven kinds of potions which consists of: a) taluhu (water) b) alipo limututu (lime flesh) sliced thinly; c) pitulobotu limututu (seven limes) cut into half; d) pitulodalala polohungo (seven kinds of croton leafs) e) yilonta (sublimated fragrance potion); f) duungo onumo (green and fragrance leaf); and g) bunga moputi (jasmine).

The seven elements are symbol of seven characters which adhere on female child; (a) nenealo character (annoyin), (b) wetetelo (speak frankly) (c) kekengolo (too nimble) (d) kureketolo (speak casually) (f) paingolo (like to argue) (g) bulabololo (speak indeterminate direction) and (h) hutatingolo/bangganga (rude). Taluhu moonu is personal symbol which is reflected on the character, attitude, and action (Lamusu, Sance, 2011).

Limu tutu (lime) in mopilihu lo limu (lemon bathing) Pohonggi u hiluwi-luwita ceremony functions as the wiper of causticities which hurt 
other people. This concept is in line with Allah command in (Surah Hujurãt : 11) which means,

"O you who believe! No people shall ridicule other people, for they may be better than them. Nor shall any women ridicule other women, for they may be better than they. Nor shall you slander one another, nor shall you insult one another with nicknames. Evil is the return to wickedness after having attained faith. Whoever does not repent-these are the wrongdoers"

That argumentation explains that Allah explains the attitudes among Mu'min. Avoid from talking about someone's ugliness, negative thinking, and hold ourselves from censuring and gossiping other people. Mopilihu Lo Limu (lemon bathing) ceremony is meaningful for parents and Gorontalo society. It is expected that children are educated from their early childhood. It is important for parents to know how meaningful this tradition to make them responsible to their children.

4. Embed Aqedah Value

Human is living between two different moral sides; be independent through his autonomy and be dependent on the nature and society.

Allah commands on His Quran surah al Anbiya' verse 92: “This community of yours is one community, and I am your Lord, so worship Me"

Allah commands humans to worship Him. Having tawhid religion means that has religion which declares that God is the One. Aqedah value on Mopolihu Lo Limu (lemon bathing) tradition is reflected on giving of bonto (symbolizing) for the female children which means that 
they will not associate partner with Allah. It is also seen from the umbrella toyungo a tool which is used in the ceremony which means that only to Allah we ask help, while wumbato (white layer) means that only to Allah we rest.

Allah commands on His Quran Surah al-Fateehah verse 5 which explains that only to God we ask worship and ask for help. It is the effect of obedient to Allah as the God who deserve to worship, and it comes from their belief that Allah is as the absolute ruler. Ask for help means that we only hope to Allah for solving and help of our problems. Mongadi Salawati (shalawat pray) ceremony teach us to always dhikr (remember Allah), pray among people, and love prophet Muhammad PBUH by emulating his words, attitude, and action.

5. Embed Social Value

Human as individual likes to stand apart however heman as social being could not be separated from other human being. Human is born, grows, becomes adult, grows old, and dies. To keep his existence, human needs other people to fulfill his needs. It deals with what Prophet Muhammad PBUH said that the better person is when he gives advantage to others. He gives benefits for his world and hereafter.

The tool which is used in Mopolihu Lo Limu ceremony which symbolizes that human living should give benefits to others is tumula (coconut shoots). Tumula (coconut shoots) means that it cultivate high social spirit, every parts of coconut from its leaf, stem, root, and fruits has function so does human should be, he should give benefits to other people by helping each other, loving each other, doing good things to other people, regard Muslim as his brother. 
6. Embed Sex Education

Molukobu (circumcision) ceremony shows that parents teach sex education to their children. Parents should put sex education into important consideration for their children. Circumcision becomes counterweight between animal lust and human lust. When human do something over, they will be likened as animal, however they are like inanimate object when they do not have any lust. Circumcision teach female children to avoid lust indulgence. They are reminded that every good and bad thing we do is written and will be rewarded or punished by Allah SWT. Something that should be taken into important consideration is that this Gorontalo tradition could be dug up, studied its meaningfulness so that it could not be vanished by the development era. one thing that should be highlighted that Islam does not prohibit its' ummah to act and to have the way of life which becomes their tradition. It was effective tradition which was used by Islam preachers in this country by acculturating local culture with Islamic teaching without leaving Islamic teaching.

7. Embed Leadership

Mopolihu Lo Limu (lemon bathing) tradition has meaning which should be understood by Gorontalo citizen as the realization of their devotion toward their culture and tradition. It is described on the activity when the child eats patodu (sugar cane) from its butt, it means that she would not be a good leader because she starts eating from the sweetest part of sugar cane then she continues to the less sugar part. On the contrary, when the child eats patodu (sugar cane) from its peak, it shows 
that she will be a good, believeable, concient leader who knows law and norms.

8. Justice

Justice means that child's attitude and action who is able to put something into its suitable portion. In this case, the writer analyzed the equipments which were used in Mopolihu Lo Limu (lemon bathing) tradition, lutu lo hulontdhi'o (gapi banana). Lutu hulontdhi'o means that child is expected to have good attitutde toward other people and she does not differentiate each other. Lutu lo hulonti'o (gapi banana) becomes the symbol of this good character.

It explains that human is expected to do not differentiate each other in his daily live. Both in terms of treating other people and living with other people.

It is expected that human lives in harmony and does not differentiate other people based on their tribes, language, and culture. Allah commands in His Qur'an Surah an-Nisa' verse 58: "God instructs you to return trusts to their rightful owners, and when you judge between people, to judge with justice. Excellent are God's instructions to you. God is Hearing, Seeing".

Sugar cane (Patodu) as the tool used in Tradisi Mopolihu Lo Limu (lemon bathing) symbolize that child is expected to have a good leadership and keep the mandate from Allah SWT. The mandate is in form of keeping the position, treasure, and so on.

9. Teach Responsibility

The equipment which is used in the Mopolihu Lo Limu (lemon bathing) tradition is Dudangata (coconut shaved). This tool is always 
needed by coconut owner. Coconut could not functions without this tool and vice versa. Popoli lomongopanggola (ancient language), hiyambola dudangata o bilulo'a o ayuwa (Coconut shaved has its place and attitude). This statement means that dudangata has been placed and it could not be moved everywhere because it deals with things in the kitchen. This analogy means that woman has role as wife and mother for her children. She prepares foods, clothes for her husband and children. Those works deal with kitchen. This symbol also teaches woman to know her position in family, manage her attitude, and avoid crime, violence, and bad doer.

The description above explains that woman by nature is born to be a wife, serve, cook, manage, and fulfill family needs. Q.S an-Nisa' verse 34 explains that it is expected that a woman to be shaliha woman, worship her God Allah, and keep herself. When she is adult and married she has duties to keep herself, keep her husband wealth, and serve her husband.

10. Love Peace and Mother Land

Love peace is symbolized with Tumula (Coconut Shoot). Tumula (shoot) is symbolized as the the power of the seeds of love which grows in a man's heart toward the girl whom he proposes to. Loves which grows higher is like a tumula (shoot) which grows to be a strong sturdy not easy fallen coconut tree which is blown by hurricane. Love mother land is symbolized with Bakohati (love box/conscience) tool which has five angles that contains traditional cosmetics; seven golden yellowish scrubs and powder to smoothes her skin. In term of religion, bakohati (love box/conscience) is a spirit box. The five angles symbolizes five principles of Gorontalo tribe. 
The five principles of Gorontalo society are: (a) Lipu poduluwalo (country is defended), (b) Bangusa taalalo (nation is guarded), (c) Batanga pomaya to lipu (willing to sacrifice for the country), (d) Upango potombulu (treasure is presented) make up (e) Nyawa podungalo (live is at stake).

According to the writer, Lipu poduluwalo (country is defended) means that when we see from the history of Gorontalo, all Gorontalo citizens took part in fighting for independence and repelled Holand invaders from Gorontalo. It means that Gorontalo citizens love their mother land through willing to sacrifice to defend their country. Thye sacrificed material and immaterial things even their thought, action, and be knowledgeable to put their nation as priority up above their personal and group affairs.

Allah commands in Quran surah Abraham verse 34 "And $\mathrm{He}$ has given you something of all what you asked. And if you were to count God's blessings, you could not enumerate them. The human being is unfair and ungrateful”.

In short, character education values in Mopolihu Lo Limu (Lemon Bathing) ceremony can be summarized in this table. Table of Character Education in Mopolihu Lo Limu (Lemon Bathing) Ceremony

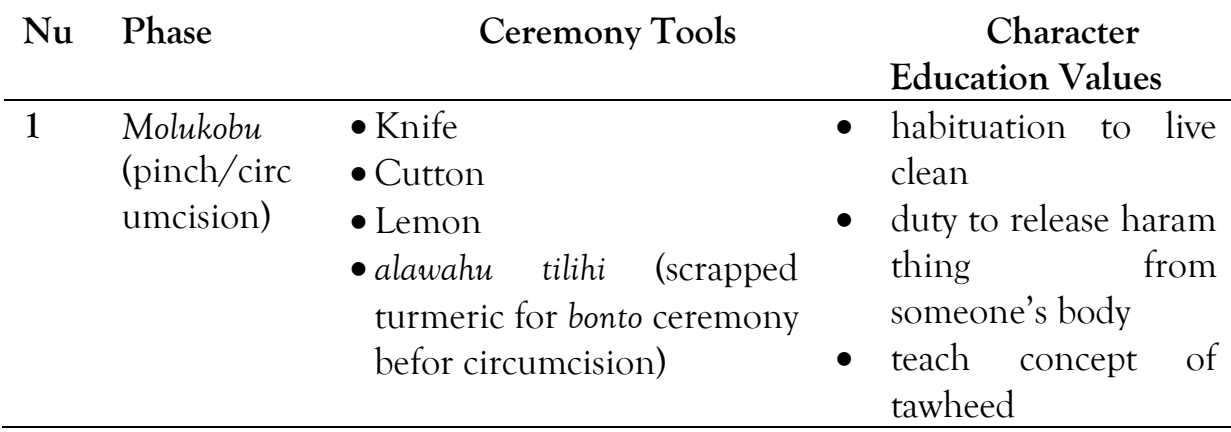


$\mathrm{Nu}$ Phase

Ceremony Tools

Character

Education Values

\begin{tabular}{|c|c|c|c|}
\hline 2 & $\begin{array}{l}\text { Mopolihu lo } \\
\text { limu } \\
\text { lemon } \\
\text { bathing) }\end{array}$ & $\begin{array}{l}\text { - Taluhu moonu (lime water } \\
\text { - Potion) } \\
\text { - } \text { Lutodu (sugar cane) } \\
\text { - (Gapi Banana) } \\
\text { - Tumula (Coconut Shoot) } \\
\text { - Polohungo To Bunggo } \\
\text { (Croton covered with } \\
\text { - Yelow Bamboo) } \\
\text { - } \text { Bulowe (Areca Nut) } \\
\text { - butito Malua Bohu (new } \\
\text { - Dudangata } \\
\text { Coconut) (Shaved }\end{array}$ & $\begin{array}{l}\text { - Habituation to live } \\
\text { - } \text { Tean } \\
\text { - Give bood attitude } \\
\text { - } \text { other people } \\
\text { - Keep the words } \\
\text { - Maintain honor } \\
\text { - Leadership } \\
\text { - Responsibility } \\
\text { - Love mother land } \\
\text { - Embed justice } \\
\text { - Tolerance } \\
\text { - Discipline } \\
\text { - Hard work } \\
\text { - Independent } \\
\text { - Social awareness } \\
\text { - Love peace } \\
\text { - Demorrtics }\end{array}$ \\
\hline 3 & $\begin{array}{l}\text { Mopohuta'o } \\
\text { to Pingge } \\
\text { (stepping } \\
\text { on plate) }\end{array}$ & $\begin{array}{l}\text { - Seven plates containing } \\
\text { coins } \\
\text { - A plate containing rice } \\
\text { grains } \\
\text { - Bakohati } \\
\text { box/coincence) } \\
\text { - Toyungo (umbrella) } \\
\text { - A plate containing soil } \\
\text { planted po'otoheto (hard } \\
\text { grass) }\end{array}$ & $\begin{array}{l}\text { - Hard work } \\
\text { - Love mother land } \\
\text { - Discipline } \\
\text { - independent } \\
\text { - reigious attitude } \\
\text { - } \text { social awareness } \\
\text { - embed graceful } \\
\text { character } \\
\text { - } \text { avoid from bad } \\
\text { attitude }\end{array}$ \\
\hline
\end{tabular}

\begin{tabular}{llll}
\hline Mongadi & - $\begin{array}{l}\text { Polutube wau bohu } \\
\text { Salawati }\end{array}$ & (burning coal and fire) & - Habituation to bless/ \\
(pray & - Taluhu ngohalati (a glass of & shalawat prophet \\
salawat) & water) & Muhammad PBUH \\
& - alama (incense) & - Adore and honor \\
& - Taluhu Salawati ( salawat & prophet Muhammad \\
& water) & - Pray each other. \\
& &
\end{tabular}


Attarbiyah: Journal of Islamic Culture and Education

https://www.attarbiyah.iainsalatiga.ac.id/index.php/attarbiyah/

\section{CONCLUSION}

Indonesian culture diversity contains values of personal and nation character development. Those value sources will be meaningless in creating community life order when we do not preserve it. for Gorontalo society, Mopolihu lo limu (Lemon Bathing) tradition is one of traditions which is threatened its existence. The meaningful Mopolihu lo limu tradition has moral messages to develop nation character which can be integrated with formal and informal education. Character education values which are in this tradition are analyzed from the aspect of ornament, and the implementation process of Mopolihu Lo Limu (lemon bathing) up to the text spelled. The characters education which are in this tradition are : (1) Religious, (2) Honest, (3) Tolerance, (4) Discipline, (5) Hard work, (6) Independent, (7) Love mother land, (8) Friendly, (9) Love peace, (10) Social awareness, (11) Environment awareness and (12) Responsible.

It is expected that, the values of Mopolihu Lo Limu (lemon bathing) could be integrated with formal and informal education. It needs good coperation among stakeholders from traditional figure, religous leader, and public figure especially young generation as the cultural heir to preserve this Gorontalo tradition Mopolihu Lo Limu. 


\section{REFERRENCES}

Alwisol. 2006. Psikologi Perkembangan. UMM Press: Malang.

Botutihe, M. dan Farha D. 2013. Tata Upacara Adat Gorontalo l dari Upacara adat kelahiran, Perkawinan, Penyambutan Tamu Penobatan dan Pemberian Gelar Adat sampai upacara adat pemakaman. s.n: Gorontalo

Fajarini, U. 2014. Peranan Kearifan Lokal dalam Pendidikan Karakter. Jurnal Sosio Didaktika. Vol 1. No. 2

Judiani, S. 2010. Implementasi Pendidikan Karakter Di Sekolah Dasar Melalui Penguatan Pelaksanaan Kurikulum. Jurnal Pendidikan dan Kebudayaan Vol. 16. No. 9

Koesoema, D. 2007. Pendidikan Karakter. Mendidik Anak di Zaman Global. Jakarta. Grasindo.

Lamusu, S. 2011. "Semiotika Dan Terapannya Pada Perangkat Pohutu Adati Lihu Lo Limu di Gorontalo". Gorontalo: Pascasarjana, Disertasi, tt.

Pemda Kabupaten Daerah Tingkat II Gorontalo bekerja sama FKIP Universitas Samratulangi Gorontalo, Empat Adat Daerah Gorontalo, Jakarta: Yayasan 23 Januari 1942-1985.

Syahbandir, M. 2010. Kedudukan Hukum Adat dalam Sistem Hukum. Jurnal Ilmu Hukum Kanum. Vol. 12. No. 1.

Susylawati, E. 2009. Eksitensi Hukum Adat dalam Sistem Hukum di Indonesia. Jurnal Al-Ihkam. Vol. 4. No. 1.

Utomo, S.B. 2003. Fiqih Aktual Jawaban Tuntas Masalah Kontemporer, Jakarta: Gema Insan Press 
Attarbiyah: Journal of Islamic Culture and Education

https://www.attarbiyah.iainsalatiga.ac.id/index.php/attarbiyah/

Vollenhoven, Cv. 201119 Lingkungan Hukum Adat. https://saripedia. wordpress.com /2011/06/13/19-lingkungan-hukum-adat-rechtsringendi-indonesia/.

Yasin, Z. dkk. 2013. Tradisi dan Kearifan Lokal Gorontalo, Gorontalo: Sultan Amay Press 